\title{
Ubiquitin Carboxyl-Terminal Hydrolase 22
}

National Cancer Institute

\section{Source}

National Cancer Institute. Ubiquitin Carboxyl-Terminal Hydrolase 22. NCI Thesaurus. Code C132058.

Ubiquitin carboxyl-terminal hydrolase 22 (525 aa, $60 \mathrm{kDa}$ ) is encoded by the human USP22 gene. This protein plays a role in the deubiquitination of histones $\mathrm{H} 2 \mathrm{~A}$ and $\mathrm{H} 2 \mathrm{~B}$. 